\title{
The Influence of Irrigation Frequency and Cultivar Blends on the Severity of Multiple Root Diseases in Sugar Beets
}

\author{
R. M. Harveson, University of Nebraska, Panhandle Research and Extension Center, 4502 Ave. I, Scottsbluff \\ 69361, and C. M. Rush, Texas Agricultural Experiment Station, P.O. Drawer 10, Bushland 79012
}

\begin{abstract}
Harveson, R. M., and Rush, C. M. 2002. The influence of irrigation frequency and cultivar blends on the severity of multiple root diseases in sugar beets. Plant Dis. 86:901-908.

The effects of cultivar mixtures and two irrigation frequency treatments were evaluated over two seasons for their impact on a complex of sugar beet root diseases in three fields infested with the fungal pathogens Aphanomyces cochliodes, Fusarium oxysporum f. sp. radicis-betae, Rhizoctonia solani, and the viral pathogen Beet necrotic yellow vein virus (BNYVV). Irrigations after emergence consisted of two or five (two 1994 studies) and three or six (1995 study) applications of water for dry and wet treatments, respectively. Cultivar treatments included MH9155, HH67, Ranger, Rhizosen, and four combinations of these same cultivars. Disease progress was monitored through destructive sampling of plants exhibiting foliar symptoms typical of root disease during the season. At harvest, data on root and sucrose yields, sucrose percentage, and a root disease index were collected. No significant irrigation $\times$ cultivar treatment interactions were observed. Few significant differences were observed between irrigation treatments involving measured yield components. Reduced irrigations however, resulted in significantly lower disease incidence in all three repeated experiments when cultivar treatments were combined. No added benefits were observed for increasing yield or decreasing root disease by planting mixed cultivars, compared to the same cultivars planted individually. Several regionally adapted cultivars performed as well or better than mixtures under the unusually high levels of disease pressure in test fields. When few alternative options are available, sugar beet growers may still benefit from reducing irrigations, and growing locally adapted cultivars in soils severely infested with root pathogens.
\end{abstract}

Root pathogens and the diseases they induce are often major constraints to profitable sugar beet production. Diseases caused by soilborne pathogens are more difficult to control than those caused by foliar pathogens, and usually cause more devastating losses to producers because they are difficult to detect before significant damage occurs (22). This hostpathogen relationship is even more complex because viable options available for managing these types of diseases are limited.

Fumigation has been shown to be effective for reducing the harmful effects of sugar beet root diseases $(11,18)$, but its use is erratic and often prohibitively expensive. Genetic resistance is another possibility for managing soilborne pathogens of sugar beets, however, this measure also has some major limitations. Breeding for resistance to pathogens such as Fusarium oxysporum f. sp. betae, Rhizoctonia solani, and Aphanomyces cochlioides is a difficult task because the inheritance of resistance is multigenic and the heritabilities are lower

Corresponding author: C. M. Rush

E-mail: cm-rush@tamu.edu

Accepted for publication 22 April 2002.

Publication no. D-2002-0528-01R

(C) 2002 The American Phytopathological Society than with single gene resistance (2). This decreases the chance of obtaining highly resistant cultivars because the presence of minor genes increases the difficulty of identifying or isolating major resistance genes $(15,16)$. Furthermore, these pathogens often are found coexisting in fields as disease complexes reducing the efficacy of genetic resistance to single pathogens. Developing new cultivars with multiple disease resistance is an even greater challenge for breeders.

One way to compensate for lack of multiple disease or stress resistance in a crop is to plant cultivar mixtures $(30,33)$. This process involves planting mixtures or blends of cultivars that have similar agronomic properties, but with different sources of disease resistance (25). The majority of studies addressing this concept have been aimed at management of polycyclic foliar diseases $(1,3,7,8,17,19,20)$. Few studies have ever attempted this approach for root diseases. Cultivar mixtures can also be beneficial in the absence of disease by mixing cultivars with slightly different growth characteristics or traits $(25,30)$.

Most soilborne pathogens of sugar beets are favored by warm and moist soil conditions $(22,27,28)$, therefore, irrigation can have profound influences on the development of certain root diseases. In the western United States, sugar beets do not attain their full yield potential without irrigation.
However, there also is the potential for severe disease to occur if too much water is applied in soils heavily infested with soilborne pathogens.

The idea for this research was originally conceived because Texas sugar beet production was experiencing severe yield reductions due in large part to a complex of soilborne pathogens. By the early 1990s, the disease situation had become so severe that seven- to eight-year rotations between crops were being recommended. Thus, this study was begun with the objective of investigating alternative methods for producing acceptable sugar beet yields in pathogen-infested fields.

Effects of irrigation on several soilborne diseases of sugar beets have been previously documented $(13,21,22,27,28)$, and irrigation management is a disease control technique that can be readily implemented by sugar beet growers with access to irrigation water. What is not known, however, is how cultivar mixtures may influence root disease in sugar beets in the presence of multiple root pathogens; or whether mixing sugar beet cultivars that differ in the possession of genetic traits such as disease resistance, high root yield capacity, or high sucrose potential would respond to multiple diseases better and yield higher than would any one cultivar individually. Therefore, the combination of irrigation frequency in conjunction with cultivar mixtures was evaluated for their ability to reduce incidence and severity of disease and/or improve measured yield components in the presence of a soilborne pathogen complex in sugar beets. Preliminary reports have been published $(12,23)$.

\section{MATERIALS AND METHODS}

The study was conducted at the USDAARS Conservation and Production Laboratory in Bushland, TX in 1994 and 1995. Tests were conducted in two separate fields in 1994, and one in 1995 on land naturally infested with multiple soilborne pathogens including $R$. solani, anastomosis group (AG 2-2), two form species of $F$. oxysporum ( $F$. oxysporum f. sp. betae and f. sp. radicis-betae) (13), A. cochlioides, and Beet necrotic yellow vein virus (BNYVV, causal agent of rhizomania, and vectored by Polymyxa betae) $(11,12,22)$. The soil was a Pullman silty clay loam (39-32-29 sand-silt-clay, $\mathrm{pH}$ 6.3, and $\mathrm{OM}$ 1.6) $(29,32)$.

Field preparation and study design. All field preparations were typical of local 
grower practices. Beds were formed on 76$\mathrm{cm}$ spacing, and anhydrous ammonia was injected $20 \mathrm{~cm}$ deep at a rate of $170 \mathrm{~kg} / \mathrm{ha}$ and incorporated in late February of each year. Nortron (ethofumasate) and Thimet (phorate) were applied and incorporated in early March at a rate of 10 liter/ha and 130 $\mathrm{g} / 3,000 \mathrm{~m}$ of row for weed and insect control, respectively. Betamix (phenmedipham) was sprayed 6 weeks after planting at 2.5 liter/ha, and Treflan (trifluralin) was applied after 9 weeks as a lay-by treatment for additional weed control.

All trials consisted of eight cultivar treatments and two irrigation treatments arranged in a randomized complete block split-plot design with six replications. Main treatments consisted of the two irrigation levels and the cultivar combinations were the subtreatments within each irrigation level. Each experimental unit (hereafter referred to as plot) consisted of four 23$\mathrm{m}$ rows.

Studies were irrigated for emergence within a week of planting (all treatments) to establish stands. The first study in 1994 was irrigated twice for emergence due to adverse weather conditions. Wet treatments consisted of five (1994) or six (1995) approximately bimonthly irrigations, which is a typical management practice for local growers. Two (1994) or three (1995) irrigations were applied at 5- to 6-week intervals for the dry treatment, and actually consisted of irrigating the entire study (both wet and dry treatments). Other than rainfall, this constituted the only water that the dry treatments received during the season after stand establishment.

All studies were furrow-irrigated using a flow rate of 1,135 liter/min (300 gallons per min). The duration of each irrigation event was until beds were completely saturated, which took approximately 10 to 12 h. During the irrigation process, stringent efforts were taken to prohibit water passing from wet treatments into dry.

Cultivar (sub) treatments included four pure line cultivars and four blend combinations that were randomized within each of the two main (wet and dry) treatments and planted 17 March and 13 April in 1994 and 21 April in 1995. Because of the high potential for seedling disease problems in the pathogen-infested fields, cultivar treatments were densely planted at a rate of 30 seeds per meter and a depth of $2 \mathrm{~cm}$. Stands were later thinned (six- to eight-true leaf growth stage) to approximately 10 to 12 plants per meter.

Cultivar treatments included Hilleshog Mono-Hy MH9155, Seedex Ranger, the two Holly cultivars, Rhizosen and HH67, and four mixture combinations of these pure lines. The mixtures consisted of Ranger in a 50:50 mixture with each of the other three (Ranger + MH9155, Ranger + Rhizosen, and Ranger + HH67) and an equal blend of all four cultivars. These four cultivars were chosen for the study because they were available commercially in Texas, and for specific genetic traits possessed by the cultivars that we wanted to evaluate.

Although Aphanomyces and Fusarium were known to be present in the test fields, no cultivars with resistance to these pathogens were available for Texas producers. However, MH9155 was included, in part, because it had previously been demonstrated to have good field tolerance to root diseases, including Aphanomyces and Fusarium root rots $(11,12,23)$. It also had strong levels of root aphid resistance, and was marketed in the area primarily as a cultivar with the capacity of producing high root yields. Ranger, like MH9155, contained resistance to root aphids, but was primarily included for its genetic ability and reputation for producing high concentrations of sucrose, but not necessarily exceptional root weights. The remaining two cultivars were selected because they each possessed resistance to diseases known to be in the complex. Rhizosen contained resistance to rhizomania, while HH67 was resistant to Rhizoctonia root and crown rot.

Data collection and harvest. Soil moisture data were recorded during the two 1994 studies, but not in 1995. Ten samples were collected randomly from the upper 10 $\mathrm{cm}$ of the soil profile within each of the two irrigation treatments using a soil core. Soil moisture was estimated from each sample gravimetrically by weighing fieldcollected soils before and after drying at $110^{\circ} \mathrm{C}$ for $24 \mathrm{~h}$. Fields were sampled five times after stand establishment, beginning

Table 1. Soil moisture data collected from the two studies conducted in 1994

\begin{tabular}{|c|c|c|c|c|}
\hline \multirow[b]{3}{*}{ Sampling dates } & \multicolumn{4}{|c|}{ Soil moisture $(\%)$} \\
\hline & \multicolumn{2}{|c|}{ Field $\mathrm{l}^{\mathrm{x}}$} & \multicolumn{2}{|c|}{ Field 2} \\
\hline & Wet $^{y}$ & Dry & Wet & Dry \\
\hline $6 / 23$ & 15.3 & $12.1 * \mathrm{z}$ & 21.7 & $13.0^{*}$ \\
\hline $7 / 6$ & 21.3 & $18.7^{*}$ & 21.8 & $18.4^{*}$ \\
\hline $8 / 1$ & 22.7 & 19.8 & 23.2 & 21.6 \\
\hline $8 / 17$ & 19.6 & 18.2 & 18.7 & 18.6 \\
\hline $8 / 26$ & 16.6 & $6.9^{*}$ & 18.7 & $9.8^{*}$ \\
\hline
\end{tabular}

${ }^{x}$ Fields 1 and 2 correspond to 1 st and 2nd plantings in 1994, respectively.

${ }^{\mathrm{y}}$ Irrigation treatments: wet (every 2 weeks) and dry (every 5 to 6 weeks).

$\mathrm{z} *$ Indicates a significant difference $(P=0.05)$ in soil moisture between wet and dry treatments according to LSD tests. in late June and continuing through August (Table 1).

During 1994 and 1995, disease counts (incidence) were made at approximately 2 week intervals beginning in June and continuing until September by destructively sampling symptomatic plants from the designated count row. The count row consisted of row four from each plot, and this same row was evaluated for the duration of the season by counting and removing infected plants from the entire $23 \mathrm{~m}$ length in each plot. Diseased plants were identified visually by typical foliar symptoms (wilting, chlorosis) resulting from root rot.

Diagnostic root symptoms allowed us to estimate the incidence of each disease from different fields while conducting root disease counts. Although fully described elsewhere $(10,11,22)$, diagnostic root symptoms will be briefly reviewed here for reader convenience. Rhizomania is recognized primarily by a severely stunted taproot with excessive proliferation of secondary rootlets, giving the root a "bearded" appearance. Rhizoctonia root rot is characterized by circular to oval, black lesions that coalesce to form larger rotted areas of the root as disease progresses. Extent of rotted tissue often is restricted to external layers of the root and does not generally penetrate into the interior until very advanced stages of disease. Symptoms of Aphanomyces root rot are easily distinguished from the black, primarily external lesions associated with Rhizoctonia root rot. A. cochlioides causes yellowish watersoaked lesions that extend into the center of the root. As disease progresses, root lesions turn black with a yellowish-brown interior, followed by disintegration of root cortical tissues, leaving only vascular strands intact. Finally, root diseases caused by Fusarium are identified by the presence of dark brown, necrotic vascular elements, which readily stand out against the white background of the beet taproot $(10,11,22)$.

Harvest data were obtained from the middle two rows, and included root and sucrose yields, sucrose percentage, and a root disease index. The last $3.8 \mathrm{~m}$ of each harvest row was dug by hand, and a root disease rating was performed on beets from this portion of the plot, which averaged 15 to 20 roots. Disease severity was rated visually on a scale of 0 to 4 as follows: Rhizoctonia, $0=$ no disease, $1=$ small, localized lesions with as much as $25 \%$ of root surface affected, $2=$ lesions coalescing with 26 to $50 \%$ of root affected, $3=51$ to $75 \%$ of root surface covered with lesions, but no internal discoloration, and 4 $=$ more than $75 \%$ of beet surface covered with lesions and internal discoloration; Aphanomyces and Fusarium, $0=$ no disease, $1=$ less than $25 \%$ of vascular elements necrotic or localized lesions on root, $2=26$ to $50 \%$ vascular necrosis or less than $10 \%$ of taproot rotted, $3=$ over $50 \%$ necrosis of vascular elements and 10 to 
$25 \%$ of taproot rotted, and $4=$ more than $25 \%$ of taproot rotted (11).

Because plots contained different numbers of beets from this area, a disease index was calculated from the root disease rating using the following equation:

$$
\begin{gathered}
D I=(D R 1 \cdot 1+D R 2 \cdot 2+D R 3 \cdot 3+ \\
D R 4 \cdot 4) /(\Sigma D R 0-4)
\end{gathered}
$$

where $D R 0=$ number of roots rated $0, D R 1$ $=$ number of roots rated 1 , etc (11). This same sub sample (15 to 20 roots) was also used to determine sucrose concentration at the Imperial Holly Sugar tare lab in Hereford, TX. The remainder of the two center rows from each plot $(19.2 \mathrm{~m})$ was then mechanically harvested in mid-October for root yield determination with a sugar beet plot harvester.

All data were subjected to analysis of variance for a split-plot test, and treatment means were separated by LSD comparisons. Correlation analysis was performed to evaluate the relationships of disease incidence with the root disease index and various yield parameters. Disease incidence is presented as cumulative disease progress curves throughout the season for each study, and as the percentage of diseased plants removed from count rows compared to the total number of plants in plots at each sampling date. Areas under the disease progress curve (AUDPC) for wet and dry treatments were calculated as:

$$
\Sigma\left(y_{i}+y_{i+1} / 2\right)\left(t_{i+1}-t_{i}\right)
$$

where the first term is the height of the rectangle and the second term is the width of the rectangle (5).

\section{RESULTS}

Because of differences among years, fields, and predominance of pathogens within fields, data from the three sites are presented separately. There were no cultivar treatment $\times$ irrigation treatment interactions observed; therefore, disease incidence data are presented as cultivar treatments combined within each of the two irrigation treatments (Figs. 1 and 2). Effects of irrigation on disease incidence of individual cultivar treatments are additionally shown in Figure 3.

Soil moisture percentages from the two irrigation treatments were found to differ significantly in three of five samples collected, with the wet treatments having higher percentages of soil moisture in these cases (Table 1). The first two samplings in August did not differ significantly between irrigation treatments. These sampling dates closely followed a period of $19 \mathrm{~cm}$ rainfall during the last 3 weeks of July (data not shown), which likely negated the soil moisture differences obtained from the irrigation treatments earlier in the season.

All three fields were infested with multiple root pathogens, however, fields differed each year in predominance of these pathogens. Fusarium oxysporum f. sp. radicis-betae was the predominant pathogen in the first planting in 1994, while the field employed for the second planting that year had higher levels of $A$. cochlioides and Beet necrotic yellow vein virus. In $1995, R$. solani was the predominant pathogen observed. The determination of pathogen predominance in fields was accomplished while destructively sampling plants for disease assessment. Although the exact number of beets infected by a specific pathogen was not documented, estimation of pathogen predominance in fields was based on observing diagnostic root symptoms described earlier $(10,11,22)$
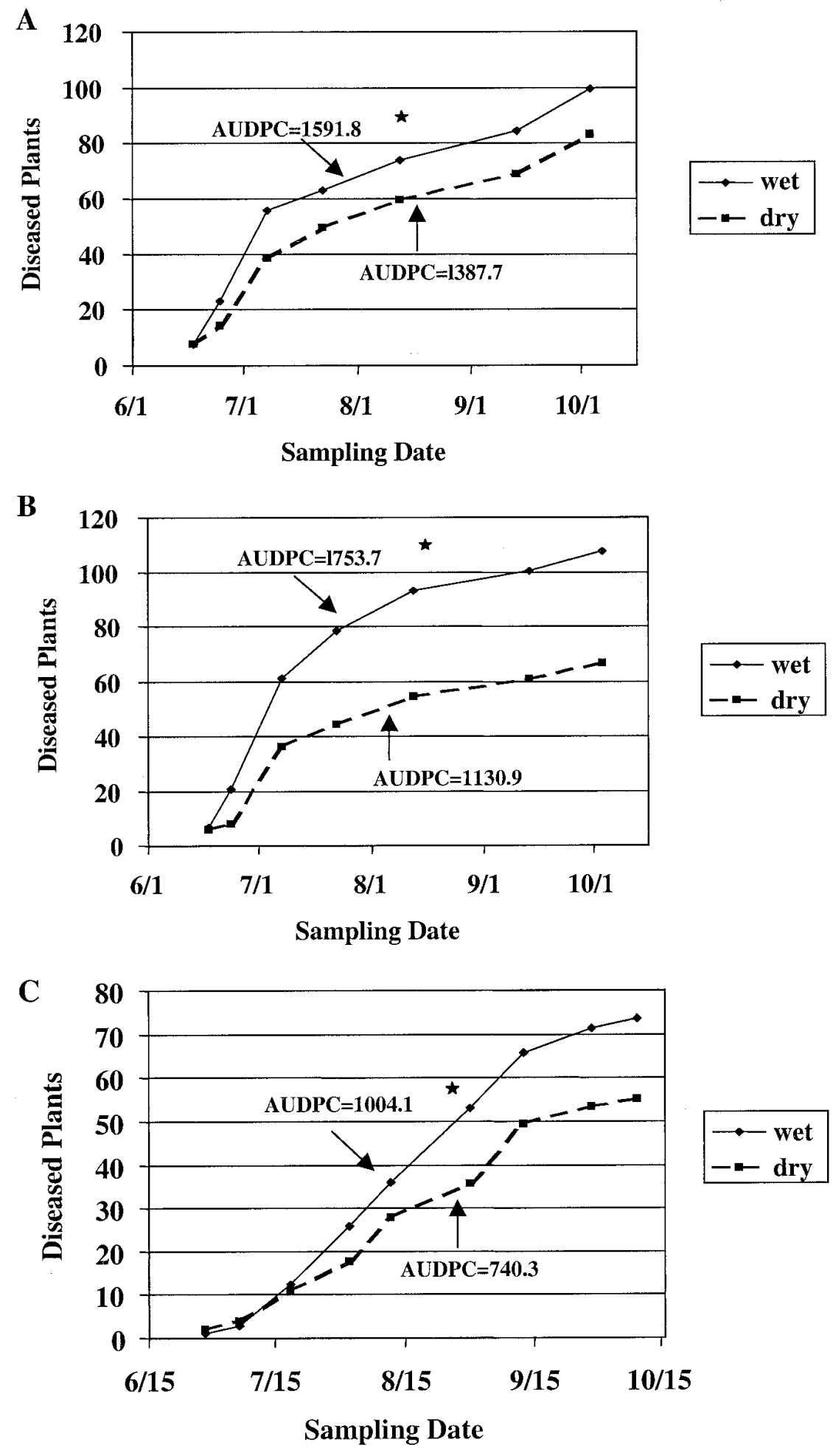

Fig. 1. Cumulative disease progress curves and estimated areas under the disease progress curve (AUDPC) for wet and dry treatments. A, First planting in 1994. B, Second planting in 1994. C, 1995 planting. Significant differences between irrigation treatments are represented by a star $(\star)$. 

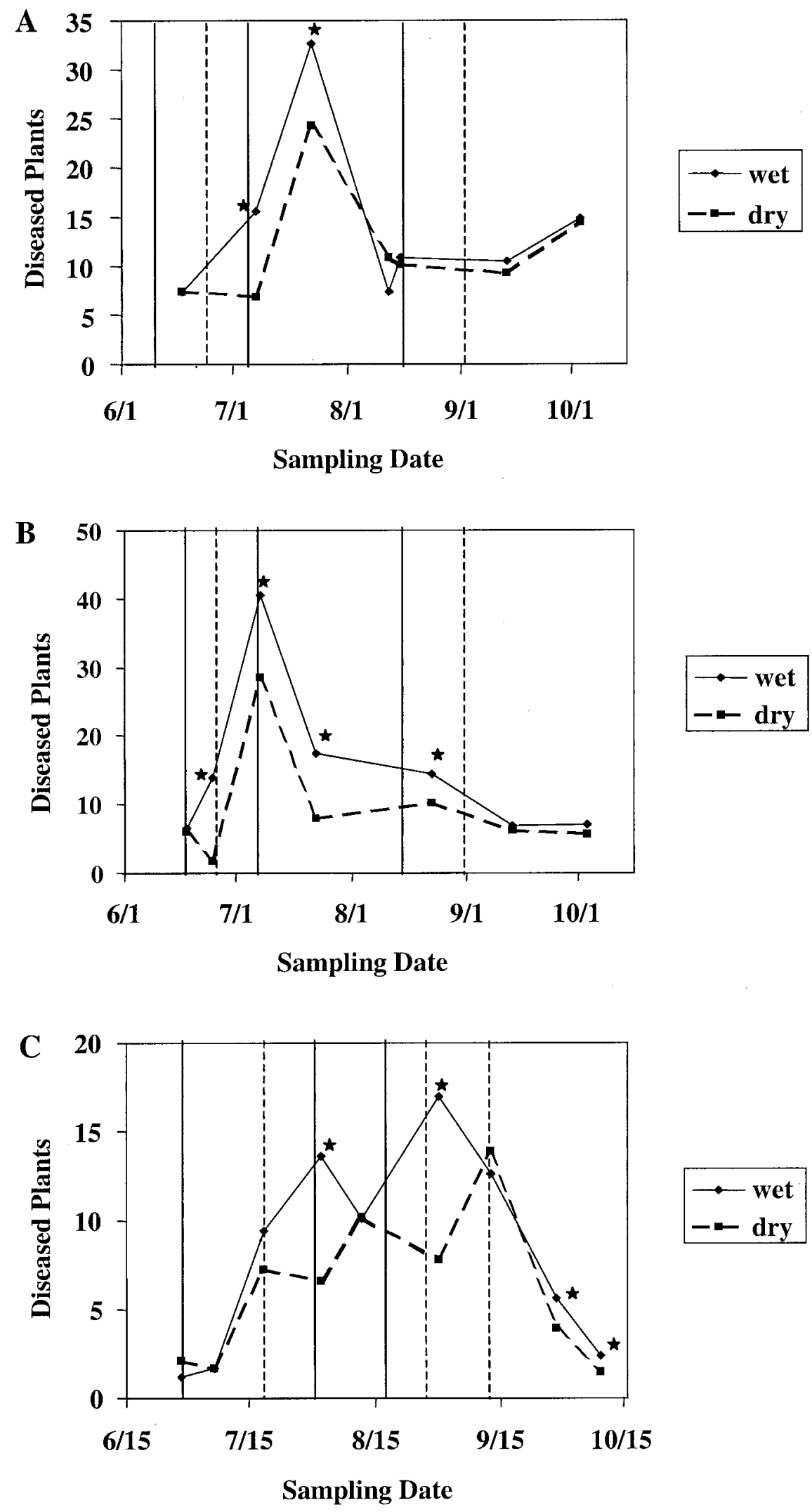

Fig. 2. Number of diseased sugar beet plants removed from both irrigation treatments at each sampling date each year of the study. Solid vertical lines depict wet irrigation treatments only, and dotted lines represent irrigations in all treatments (dry treatment). A, First planting in 1994. B, Second planting in 1994. C, 1995 planting. Significant differences between irrigation treatments are represented by a star $(\star)$. while removing infected plants from disease count rows.

Regardless of the pathogens found predominating in fields, disease incidence was still significantly increased by higher irrigation frequencies from all three studies when cultivar treatments were combined. This is most readily observed in the disease progress curves and AUDPC values (Figs. 1A to $1 \mathrm{C}$ ). The significantly higher disease counts observed from wet treatments in July 1994 also corresponded closely to the first two soil moisture evaluations (Table 1 and Figs. 2A and 2B). The significantly different soil moisture content obtained from these sampling dates also help to confirm that higher levels of moisture (and irrigation) can promote greater root disease problems in sugar beets from this group of pathogens. This same relationship between soil moisture and disease could not be shown the following year, as soil moisture was not monitored in the 1995 study. However, there were similarly higher numbers of diseased plants identified from the wet irrigation treatments as was observed in 1994 (Figs. 1C and 2C).

When disease incidence among individual cultivar treatments was evaluated, a different relationship was revealed, which showed more variation existing between repeated studies than with combined cultivar treatments. In the first planting in 1994, only one cultivar treatment resulted in significantly greater disease incidence in wet plots (Fig. 3A). The second planting in 1994 and the 1995 test had 75 and $63 \%$ of treatments, respectively, that were significantly higher in wet plots (Figs. 3B and 3C). Those treatments in the latter two studies that were not significantly different between irrigation treatments included both MH9155 and Ranger (Figs. 3B and 3C).

Yield information from studies collected at harvest was much less definitive compared to the disease incidence data. All yield components are important and play a vital role in production, however, sucrose yield is often considered to be the best measure for total sugar beet yields since it is the product of clean root yield (tonnage) and percent sucrose. Therefore, as it best represents how growers derive income from the crop, it was chosen as the yield parameter for comparing performance of treatments.

Sucrose yields from cultivar treatments were all higher in the wet plots from the first planting in 1994, with one-half being significantly higher (Table 2). This is in contrast to the other two studies, which both produced higher yields in dry plots with the exception of one treatment (Tables 3 and 4). Less than one-half of the treatments ( 7 of 16) from the latter two studies were significantly different, however those treatments that were different always included MH9155 and HH67. These same two cultivars were also consistently among 
the highest sucrose producers than other treatments regardless of irrigation treatment employed (Tables 2 to 4). Sucrose yields from treatments that included Rhizosen (excluding the 4-way combination) were consistently and significantly lower than those including MH9155 and HH67 (Tables 2 to 4).

Disease severity was additionally evaluated by a root disease index calculated from root disease ratings taken at harvest from each plot. This index showed that a greater degree of root infection was present in wet plots for all studies, although few were statistically significant from the first 1994 planting or the 1995 planting (Tables 2 and 4). Overall, the second planting in 1994 exhibited higher levels of root disease in the wet plots than the other two studies, with $75 \%$ of disease indices being significant (Table 3). This observation is likely explained by the higher concentrations of rhizomania and Aphanomyces root rot observed in this field. Aphanomyces root rot is caused by a zoosporiferous pathogen, and rhizomania is a virus disease transmitted to plants by the zoosporiferous plasmodiophorid, Polymyxa betae. Although $P$. betae is not rapidly spread by irrigation water within fields alone (14,31), high levels of soil moisture have been demonstrated to increase the incidence and severity of both rhizomania and Aphanomyces root rot $(21,22,24,27)$.

Correlations that compared disease incidence and various yield parameters were highly significant (Table 5), further illustrating the severe effects that root diseases can have on sugar beets under conducive conditions. In general, the higher correlations were obtained after separation of data into irrigation treatments, and not with the combined results. Disease incidence did not correlate with percent sucrose as well as it did with the other measured yield data (Table 5). All other parameters were highly correlated with disease incidence in all three studies, including disease index (positively), and root and sucrose yields (negatively) (Table 5).

\section{DISCUSSION}

Once soilborne pathogens become established in fields they are notoriously difficult to control. Growers must learn to manage them as they occur, as they are not likely to ever be completely eradicated. This study was designed and conducted with the purpose of testing practical methods for addressing root disease problems in sugar beets, including specific techniques that could be easily adapted into conventional production systems in Texas. It is also unique because it represents the first attempt to evaluate cultivar mixtures as a technique for managing multiple root diseases.

It had been previously noted that infection by these soilborne pathogens in Texas tended to occur very early in the season (early June) when plants were in the six- to eight-true leaf stage (R. M. Harveson and C. M. Rush, unpublished). It would have been typical in Texas for a grower to irrigate the crop for emergence, and in some instances, to even preirrigate fields before planting. These practices, in concert with rapidly warming soil temperatures in spring, likely caused much earlier infection than producers ever realized. Since we surmised that infection did occur early, we also concluded that little could be done to
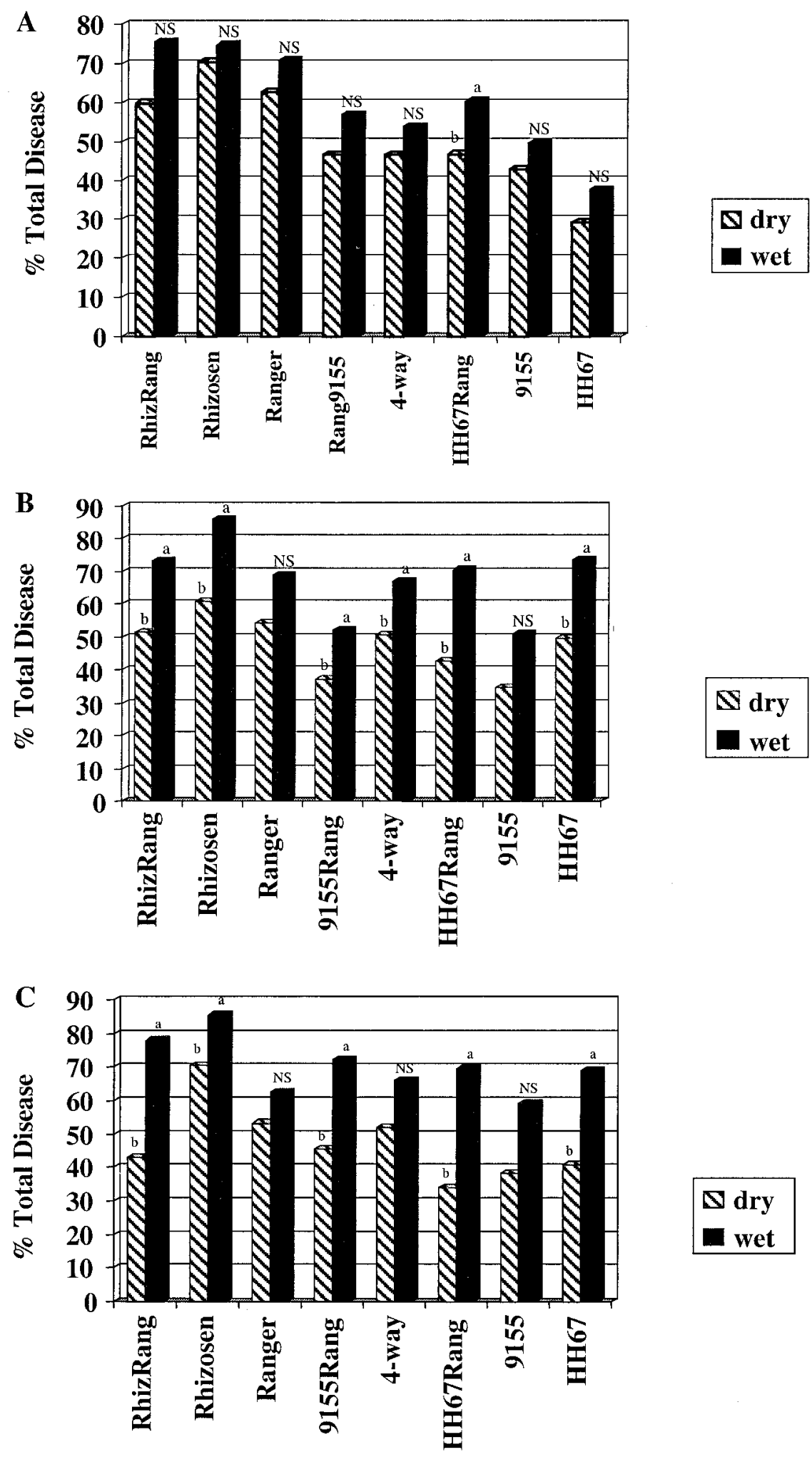

Fig. 3. Percentage of infected sugar beet plants grown as pure lines or in cultivar mixtures removed from wet and dry plots A, First planting in 1994. B, Second planting in 1994. C, 1995 planting. Significant differences between irrigation treatments are shown with different letters. Irrigation treatments not significantly different are designated with 'NS'. 
manage this problem afterward except by reducing irrigation throughout the season, or using genetic resistance. Because of the presence of multiple root pathogens, and a paucity of cultivars possessing multiple disease resistance, cultivar mixtures that varied in their genetic backgrounds seemed a valid technique to evaluate in conjunction with irrigation reductions.

Sugar beets are somewhat unique among crop plants because there are several cultivar traits besides total yield potential that are considered in order to achieve successful production. These include root yields, sucrose yields, and sucrose percentage in taproots. All these factors are independent, yet their interactions (e.g., sucrose yield) can also collectively influence profitable yields. In addition to disease resistance, cultivars are available today that have been bred to specifically address other desired agronomic traits such as high root yields or high sucrose concentrations. Therefore, our major goal in selecting cultivars for inclusion in these studies was to evaluate whether a high sucrose cultivar (Ranger) combined with cultivars with specific dis- ease resistance (Rhizosen and HH67) or high root yield capacity and field disease tolerance (MH9155) would respond to multiple soilborne pathogens and yield more effectively than any one of the cultivars grown by itself as a pure line.

This concept of mixing cultivars possessing different genes or levels of disease resistance has been tested numerous times over the years with varying degrees of success. Most of these efforts have been attempted for managing foliar diseases of cereals $(1,3,7,17,19,20)$. Mixtures of various winter wheat cultivars have successfully increased yields, and decreased disease severity in the presence of stripe rust (7), leaf rust (17), and eyespot (20). Other studies using wheat mixtures for yellow rust (3), or Septoria blotch control (19) or barley mixtures for scald reduction (1) have showed little or no yield improvement or disease reduction in comparison to associated pure lines.

Cultivar mixtures for disease control in sugar beets have also been investigated over several seasons, but only for two foliar diseases (8). Curly top and Cerco- spora leaf spot-resistant sugar beet cultivars were blended in three ratios and compared to each pure line grown individually. Responses were erratic among years, but yields of blend treatments were shown to be generally lower than the highest yielding leaf spot resistant cultivar grown individually (8).

Very few reports have ever been published that have evaluated the potential benefits of utilizing cultivar mixtures as a technique for reducing effects of soilborne diseases. One successful example involved blending several ratios of two wheat cultivars that were either resistant or susceptible to Soilborne wheat mosaic virus (SBWMV). This pathogen is similar to BNYVV by being vectored by the soilborne plasmodiophorid, Polymyxa and infecting host roots. Viral infection was substantially reduced (32 to $40 \%$ ) in mixtures compared to the susceptible wheat pure line (9). Conversely, Bowen and Schapaugh (4) found that there was no real advantage in blending pure lines of soybeans, either in increased yield or decreased charcoal rot infection.

Table 2. Yield and disease index for sugar beets grown in wet (W, irrigated every 2 weeks) and dry (D, irrigated every 5 to 6 weeks) plots from the first planting in 1994

\begin{tabular}{|c|c|c|c|c|c|c|c|c|}
\hline \multirow[b]{2}{*}{ Cultivar treatment ${ }^{\mathrm{x}}$} & \multicolumn{2}{|c|}{ Root yieldu } & \multicolumn{2}{|c|}{ Sucrose \% } & \multicolumn{2}{|c|}{ Sucrose yield $^{v}$} & \multicolumn{2}{|c|}{ DI $^{w}$} \\
\hline & $\mathbf{W}^{\mathbf{y}}$ & D & $\mathbf{W}$ & D & $\mathbf{W}$ & D & $\mathbf{W}$ & D \\
\hline MH9155 & 39.5 & $28.5 \mathrm{a}$ & $13.0 \mathrm{abc}$ & $12.3 \mathrm{a}$ & $4707.6 \mathrm{a}$ & $3586.7 \mathrm{a}$ & $1.8 \mathrm{~d}$ & $1.9 \mathrm{bc}$ \\
\hline MH9155Rang & $30.9 \mathrm{abc}$ & $29.1 \mathrm{a}$ & $13.3 \mathrm{a}^{* \mathrm{z}}$ & $11.6 \mathrm{ab}$ & $4483.4 \mathrm{a}$ & $3138.4 \mathrm{ab}$ & $2.1 \mathrm{~cd}$ & $2.0 \mathrm{bc}$ \\
\hline HH67 & $30.7 \mathrm{ab}$ & $29.6 \mathrm{a}$ & $12.4 \mathrm{~cd} *$ & $11.5 \mathrm{ab}$ & $4259.2 \mathrm{ab}$ & $2914.2 b^{*}$ & $1.8 \mathrm{~d}$ & $1.5 \mathrm{c}$ \\
\hline 4-way & $27.4 \mathrm{bcd}$ & $21.5 \mathrm{bc}$ & $12.5 b c$ & $11.4 \mathrm{~b}$ & $3810.9 \mathrm{ab}$ & $2690.0 \mathrm{~b}^{*}$ & $2.3 \mathrm{bc}$ & $2.1 \mathrm{~b}$ \\
\hline HH67Rang & $30.9 \mathrm{abc}$ & $23.3 \mathrm{ab}^{*}$ & $13.2 \mathrm{ab} *$ & $11.8 \mathrm{ab}$ & $3586.7 \mathrm{~b}$ & $2580.3 \mathrm{~b}^{*}$ & $2.1 \mathrm{~cd}$ & $1.9 \mathrm{bc}$ \\
\hline Ranger & $19.3 \mathrm{de}$ & $17.7 \mathrm{bc}$ & $11.9 \mathrm{~d}$ & $11.6 \mathrm{ab}$ & $2690.0 \mathrm{c}$ & $2241.7 \mathrm{c}$ & $2.8 \mathrm{a}$ & $2.7 \mathrm{a}$ \\
\hline RhizRang & 21.3 cde & $17.3 \mathrm{bc}$ & $13.0 \mathrm{abc}$ & $12.1 \mathrm{ab}$ & $2465.9 \mathrm{c}$ & $2017.5 \mathrm{~cd}$ & $2.6 \mathrm{abc}$ & $2.4 \mathrm{ab}$ \\
\hline Rhizosen & $15.6 \mathrm{e}$ & $14.6 \mathrm{c}$ & 12.9abc & $12.3 \mathrm{a}$ & $2241.7 \mathrm{c}$ & $1569.2 \mathrm{~d}^{*}$ & $2.7 \mathrm{ab}$ & $2.4 \mathrm{ab}$ \\
\hline
\end{tabular}

u Metric tons per ha.

${ }^{v}$ Kilograms sucrose per ha.

${ }^{\mathrm{w}} \mathrm{DI}=$ disease index: a weighted average of beets from $3.8 \mathrm{~m}$ hand harvested plots rated individually on a $0-4$ scale with $0=\mathrm{a}$ healthy root and $4=\mathrm{a}$ completely rotted root. $\mathrm{DR}=$ disease rating. Disease index was then calculated by the following equation: $\mathrm{DI}=(\mathrm{DR} 1 \cdot 1+\mathrm{DR} 2 \cdot 2+\mathrm{DR} 3 \cdot 3+\mathrm{DR} 4 \cdot 4) /(\Sigma \mathrm{DR} 0-$ 4).

$x$ Blends are 50 or $25 \%$ for each cultivar.

${ }^{\mathrm{y}}$ Means within a column followed by the same letter are not statistically different according to LSD tests $(P=0.05)$.

$\mathrm{z}$ * Indicates a significant difference $(P=0.05)$ between $\mathrm{W}$ and $\mathrm{D}$ plots according to LSD tests.

Table 3. Yield and disease index for sugar beets grown in wet (W, irrigated every 2 weeks) and dry (D, irrigated every 5 to 6 weeks) plots from the second planting in 1994

\begin{tabular}{|c|c|c|c|c|c|c|c|c|}
\hline \multirow[b]{2}{*}{ Cultivar treatment ${ }^{\mathrm{x}}$} & \multicolumn{2}{|c|}{ Root yield $^{\mathrm{u}}$} & \multicolumn{2}{|c|}{ Sucrose \% } & \multicolumn{2}{|c|}{ Sucrose yield $^{\mathbf{v}}$} & \multicolumn{2}{|c|}{ DI $^{\mathbf{w}}$} \\
\hline & $\mathbf{W}^{\mathbf{y}}$ & D & $\mathbf{W}$ & D & $\mathbf{W}$ & D & $\mathbf{W}$ & D \\
\hline MH9155 & $34.3 \mathrm{ab}$ & $38.1 \mathrm{ab} * \mathrm{z}$ & $13.0 \mathrm{bc}$ & $12.7 \mathrm{ab}$ & $3586.7 \mathrm{ab}$ & $4035.1 \mathrm{ab}^{*}$ & $2.2 \mathrm{bc}^{*}$ & $1.8 \mathrm{a}$ \\
\hline MH9155Rang & $38.6 \mathrm{ab}$ & $42.2 \mathrm{a}^{*}$ & $13.5 \mathrm{a}$ & $12.8 \mathrm{ab}$ & $4035.1 \mathrm{a}$ & $4228.1 \mathrm{a}$ & $2.2 \mathrm{bc}$ & $2.0 \mathrm{a}$ \\
\hline HH67 & $30.7 \mathrm{ab}$ & $33.0 \mathrm{ab}$ & $13.0 \mathrm{bc}$ & $11.9 \mathrm{~b}$ & $2465.9 \mathrm{~b}$ & $3138.4 \mathrm{ab}^{*}$ & $2.5 \mathrm{abc}^{*}$ & $1.9 \mathrm{a}$ \\
\hline 4-way & $40.6 \mathrm{a}$ & $42.8 \mathrm{a}$ & $13.6 \mathrm{a}$ & $13.1 \mathrm{a}$ & $3986.1 \mathrm{a}$ & $4064.2 \mathrm{a}$ & $2.1 \mathrm{c}$ & $1.9 \mathrm{a}$ \\
\hline HH67Rang & $22.6 \mathrm{~b}$ & $29.8 \mathrm{ab}^{*}$ & $12.7 \mathrm{c}$ & $12.5 \mathrm{ab}$ & $2465.9 \mathrm{~b}$ & $3092.4 \mathrm{ab}^{*}$ & $2.8 \mathrm{a}^{*}$ & $2.2 \mathrm{a}$ \\
\hline Ranger & $28.3 \mathrm{ab}$ & $27.4 \mathrm{~b}$ & $12.9 \mathrm{bc}$ & $11.9 \mathrm{~b}$ & $2630.0 \mathrm{bc}$ & $2465.9 \mathrm{bc}$ & $2.6 \mathrm{ab}^{*}$ & $2.3 \mathrm{a}$ \\
\hline RhizRang & $26.6 \mathrm{ab}$ & $31.4 \mathrm{ab}^{*}$ & $12.9 \mathrm{bc}$ & $12.3 \mathrm{ab}$ & $2582.1 \mathrm{bc}$ & $2914.2 \mathrm{abc}$ & $2.8 \mathrm{a}^{*}$ & $2.2 \mathrm{a}$ \\
\hline Rhizosen & $26.2 \mathrm{ab}$ & $24.5 \mathrm{~b}$ & $12.9 \mathrm{bc}$ & $12.5 \mathrm{ab}$ & $2017.5 \mathrm{c}$ & $2238.6 \mathrm{c}$ & $2.5 a b c *$ & $2.2 \mathrm{a}$ \\
\hline
\end{tabular}

u Metric tons per ha.

${ }^{\mathrm{v}}$ Kilograms sucrose per ha.

${ }^{\mathrm{w}} \mathrm{DI}=$ disease index: a weighted average of beets from $3.8 \mathrm{~m}$ hand harvested plots rated individually on a $0-4$ scale with $0=\mathrm{a}$ healthy root and $4=\mathrm{a}$ completely rotted root. DR=disease rating. Disease index was then calculated by the following equation: DI $=(\mathrm{DR} 1 \cdot 1+\mathrm{DR} 2 \cdot 2+\mathrm{DR} 3 \cdot 3+\mathrm{DR} 4 \cdot 4) /(\Sigma \mathrm{DR} 0-$ 4).

${ }^{x}$ Blends are $50 \%$ or $25 \%$ for each cultivar.

y Means within a column followed by the same letter are not statistically different according to LSD tests $(P=0.05)$.

$\mathrm{z} *$ Indicates a significant difference $(P=0.05)$ between $\mathrm{W}$ and $\mathrm{D}$ plots according to LSD tests $(P=0.05)$. 
The results of the current study exploring this concept in the presence of a complex of sugar beet root pathogens have similarly exhibited a lack of definitive benefit from using cultivar mixtures compared to the pure lines grown individually. The mixtures, including Ranger, did not compensate lower root yields with higher sucrose concentrations. Rhizosen, although resistant to one of the pathogens in the complex (BNYVV), was routinely among the worst treatments for every category measured. This observation is consistent with prior studies, and demonstrated once again its extreme susceptibility to the fungal root rots in the disease complex caused by $A$. cochliodes, $F$. oxyporum, and $R$. solani. $(11,12,23)$.

It is not surprising that the higher levels of irrigation during the two studies conducted in 1994 corresponded with higher soil moisture percentages and root disease counts after combining cultivar data. Though soil moisture data were not collected during 1995, a similar relationship was observed between wet plots and numbers of diseased plants identified in the field (Figs. 1C and 2C). What is somewhat surprising is the inconsistency between irrigation treatments in terms of yield results. Although not always significant, the first planting in 1994 tended to result in higher yields (both sucrose and root) from the wet treatments, whereas better yields were usually obtained from the dry treatments from the other two studies.

Higher soil moisture levels resulted in higher disease incidence, and the correlation analyses further suggested that disease significantly influenced yield parameters. However, root disease, as measured throughout the growing season from disease counts, did not consistently relate to subsequent yield reductions in specific cultivar treatments. One possible explanation for these observations concerns the nature of the pathogenic organisms themselves. Root pathogens such as $R$. solani and their impact on yield have often proven difficult to consistently quantify (26). The combination of multiple root pathogens (including $R$. solani) in this study, their uneven clustered distribution within fields, and fluctuating soil environmental conditions likely contributed to such a high degree of variation that many potential differences may have been obscured in the plots.

Nevertheless, two important positive findings were still identified from this study. One involved the effectiveness of several locally adapted cultivars used as pure lines. Within each irrigation treatment, MH9155 and HH67 consistently resulted in improved sucrose yields compared with Rhizosen (Tables 2 to 4), which had been widely used in the area, as it was one of the first rhizomania resistant cultivars available. The improved performance of these two cultivars under these conditions may also be explained by their pedigrees. Both were bred and selected for producing under environmental conditions typical of Texas, whereas Rhizosen was originally developed for use in California. In fact, the field used for the first 1994 study had previously been a root disease nursery, and selections for these cultivars may very well have been made in that exact location years earlier. MH9155 had no specific disease resistance, yet its relative success under the severe conditions of this study suggests that good overall field tolerance and local adaptation may be as effective or better than cultivars with specific disease resistance to a single pathogen found in the complex.

The other encouraging aspect observed from this study suggests that growers may readily benefit from reduced irrigations in situations where root diseases are problematic. With the exception of the first planting in 1994, dry plot yields from the second 1994 and 1995 studies were equal to or better than those from wet plots. Therefore, in those situations, growers would have

Table 4. Yield and disease index for sugar beets grown in wet (W, irrigated every 2 weeks) and dry (D, irrigated every 5 to 6 weeks) plots from the 1995 planting

\begin{tabular}{|c|c|c|c|c|c|c|c|c|}
\hline \multirow[b]{2}{*}{ Cultivar treatment ${ }^{x}$} & \multicolumn{2}{|c|}{ Root yieldu $^{u}$} & \multicolumn{2}{|c|}{ Sucrose \% } & \multicolumn{2}{|c|}{ Sucrose yieldv } & \multicolumn{2}{|c|}{$\mathbf{D I}^{\mathbf{w}}$} \\
\hline & $\mathbf{W}^{\mathbf{y}}$ & D & $\mathbf{W}$ & D & $\mathbf{W}$ & D & $\mathbf{W}$ & D \\
\hline MH9155 & $22.0 \mathrm{a}$ & $21.1 \mathrm{a}$ & $14.5 \mathrm{a}$ & $15.2 \mathrm{ab}$ & $2465.9 \mathrm{a}$ & $3138.4 \mathrm{a}^{* \mathrm{z}}$ & $3.0 \mathrm{ab}^{*}$ & $2.7 \mathrm{~b}$ \\
\hline MH9155Rang & $19.1 \mathrm{ab}$ & $15.5 \mathrm{ab}$ & $15.1 \mathrm{a}$ & $14.7 \mathrm{ab}$ & $1793.4 \mathrm{ab}$ & $2626.4 \mathrm{a}^{*}$ & $2.5 \mathrm{~b}$ & $2.9 \mathrm{ab}$ \\
\hline HH67 & $11.6 \mathrm{~b}$ & $16.1 \mathrm{a}$ & $14.6 \mathrm{a}$ & $15.4 \mathrm{ab}$ & $2017.5 \mathrm{ab}$ & $2690.0 \mathrm{a}^{*}$ & $3.2 \mathrm{a}^{*}$ & $2.4 \mathrm{~b}$ \\
\hline 4-way & $16.8 \mathrm{ab}$ & $19.7 \mathrm{a}$ & $14.7 \mathrm{a}$ & $15.4 \mathrm{ab}$ & $1345.0 \mathrm{~b}$ & $2241.7 \mathrm{a}$ & $3.1 \mathrm{ab}$ & $2.7 \mathrm{~b}$ \\
\hline HH67Rang & $16.4 \mathrm{ab}$ & $21.3 \mathrm{a}$ & $15.0 \mathrm{a}$ & $14.2 \mathrm{~b}$ & $1569.2 \mathrm{ab}$ & $2465.9 a^{*}$ & $3.1 \mathrm{ab}^{*}$ & $2.5 \mathrm{~b}$ \\
\hline Ranger & $20.4 \mathrm{ab}$ & $20.8 \mathrm{a}$ & $14.8 \mathrm{a}$ & $16.0 \mathrm{a}$ & $2017.5 \mathrm{ab}$ & $2587.3 \mathrm{a}$ & $3.0 \mathrm{ab}$ & $2.5 \mathrm{~b}$ \\
\hline RhizRang & $16.4 \mathrm{ab}$ & $18.2 \mathrm{a}$ & $14.4 \mathrm{a}$ & $15.0 \mathrm{ab}$ & $1534.6 \mathrm{ab}$ & $2440.2 \mathrm{a}$ & $3.1 \mathrm{ab}$ & $2.9 \mathrm{ab}$ \\
\hline Rhizosen & $8.3 \mathrm{c}$ & $9.6 \mathrm{~b}$ & $14.3 \mathrm{a}$ & $14.7 \mathrm{ab}$ & $448.3 \mathrm{c}$ & $896.7 \mathrm{~b}$ & $3.7 \mathrm{a}$ & $3.3 \mathrm{a}$ \\
\hline
\end{tabular}

u Metric tons per ha.

${ }^{\mathrm{v}}$ Kilograms sucrose per ha.

${ }^{\mathrm{w}} \mathrm{DI}=$ disease index: a weighted average of beets from $3.8 \mathrm{~m}$ hand harvested plots rated individually on a 04 scale with $0=\mathrm{a}$ healthy root and $4=\mathrm{a}$ completely rotted root. DR=disease rating. Disease index was then calculated by the following equation: DI $=(\mathrm{DR} 1 \cdot 1+\mathrm{DR} 2 \cdot 2+\mathrm{DR} 3 \cdot 3+\mathrm{DR} 4 \cdot 4) /(\Sigma \mathrm{DR} 0-4)$.

$x$ Blends are $50 \%$ or $25 \%$ for each cultivar.

${ }^{y}$ Means within a column followed by the same letter are not statistically different according to LSD tests $(P=0.05)$.

$\mathrm{z} *$ Indicates a significant difference $(P=0.05)$ between $\mathrm{W}$ and D plots according to LSD tests.

Table 5. Disease correlations between yield parameters and percentage of diseased plants removed from plots in the first and second plantings in 1994 and the 1995 planting

\begin{tabular}{|c|c|c|c|c|c|c|c|c|c|}
\hline & \multicolumn{3}{|c|}{$\begin{array}{c}\text { Combined(r) }^{\mathbf{v}} \\
\text { PTOTDIS }^{w}\end{array}$} & \multicolumn{3}{|c|}{$\begin{array}{l}\text { Wet plots(r) } \\
\text { PTOTDIS }\end{array}$} & \multicolumn{3}{|c|}{$\begin{array}{c}\text { Dry plots(r) } \\
\text { PTOTDIS }\end{array}$} \\
\hline & 1994 a & $1994 \mathrm{~b}$ & 1995 & $1994 \mathrm{a}$ & $1994 \mathrm{~b}$ & 1995 & 1994 a & $1994 \mathrm{~b}$ & 1995 \\
\hline$\%$ Sucrose & -0.03 & -0.10 & $-0.46 * *$ & -0.27 & $-0.32 *$ & $-0.54 * *$ & -0.08 & $-0.48 * *$ & $-0.37 * *$ \\
\hline Root yield ${ }^{x}$ & $-0.60 * *$ & $-0.56^{* *}$ & $-0.56^{* *}$ & $-0.66^{* *}$ & $-0.60 * *$ & $-0.58 * *$ & $-0.75 * *$ & $-0.62 * *$ & $-0.57 * *$ \\
\hline Sucrose yield ${ }^{y}$ & $-0.53 * *$ & $-0.55^{* *}$ & $-0.60 * *$ & $-0.62 * *$ & $-0.61^{* *} *$ & $-0.65 * *$ & $-0.74 * *$ & $-0.66 * *$ & $-0.54 * *$ \\
\hline $\mathrm{DI}^{\mathrm{z}}$ & $0.66 * *$ & $0.70 * *$ & $0.57 * *$ & $0.71 * *$ & $0.63 * *$ & $0.54 * *$ & $0.60 * *$ & $0.56^{* *}$ & $0.43 * *$ \\
\hline
\end{tabular}

${ }^{v}$ Correlation coefficient; $*=$ significant $(P=0.05) * *=$ significant $(P=0.01)$

${ }^{w}$ Percent total disease: percentage of plants removed from count row in plots because of disease.

${ }^{x}$ Metric tons per ha.

${ }^{y}$ Kilograms sucrose per ha.

${ }^{\mathrm{z}} \mathrm{DI}=$ disease index: a weighted average of beets from $3.8 \mathrm{~m}$ hand harvested plots rated individually on a $0-4$ scale with $0=\mathrm{a}$ healthy root and $4=\mathrm{a}$ completely rotted root. $\mathrm{DR}=$ disease rating. Disease index was then calculated by the following equation: DI $=(\mathrm{DR} 1 \cdot 1+\mathrm{DR} 2 \cdot 2+\mathrm{DR} 3 \cdot 3+\mathrm{DR} 4 \cdot 4) /(\Sigma \mathrm{DR} 0-$ 4). 
profited by reducing costs of irrigation and reducing numbers of diseased plants, while still producing equal or better yields compared to those plots with higher levels of irrigation. A similar study using sprinkler irrigation in a commercial grower's field under less severe infestation levels demonstrated that reduced irrigations could result in significantly higher root and sugar yields in addition to lowered disease incidence (6). The slightly higher yield improvements that were obtained from the wet plots in the first planting in 1994, most likely became negligible when coupled with costs of two to three extra irrigations.

This study was conducted to develop measures that would enable Texas sugar beet growers to maintain sustainability and competitiveness by cutting expenses, improving yield quality, and reducing potential pathogen carryover in heavily infested soils without abandoning fields to sugar beet production. The results are particularly encouraging when the degree of pathogen infestation is considered. Pathogen populations in the fields used in this two-year study were extremely high because beets had been grown in the research area for 4 of the 10 years preceding this study, and were greater than most commercial producers would typically encounter. Although the benefits of employing mixtures of cultivars varying in genetic backgrounds were limited, it was still concluded to be advantageous to combine reduced irrigation frequencies with the use of locally adapted cultivars. This study was conducted with Texas in mind, yet the same concept should be valid in any other irrigated sugar beet-producing area with root disease problems.

\section{LITERATURE CITED}

1. Abbott, D. C., Burdon, J. J., Brown, A. H. D., Read, B. J., and Bittisnich, D. 2000. The incidence of barley scald in cultivar mixtures. Aust. J. Agric. Res. 51:355-360.

2. Afanasiev, M. M., and Sharp, E. L. 1961. Testing of inbred lines of sugar beets for resistance to aphanomyces, rhizoctonia, and fusarium root rots. J. Am. Soc. Sugar Beet Technol. 11:542-546.

3. Akanda, S. I., and Mundt, C. C. 1997. Effect of two-component cultivar mixtures and yellow rust on yield and yield components of wheat. Plant Pathol. 46:560-580.

4. Bowen, C. R., and Schapaugh, W. T. 1989.
Relationships among charcoal rot infection, yield, and stability estimates in soybean blends. Crop Sci. 29:42-46.

5. Campbell, C. L., and Madden, L. V. 1990. Introduction to plant disease epidemiology. John Wiley and Sons, New York.

6. Fahnert, M. L. 1999. LEPA irrigation amounts and frequency for control of sugar beet pathogens in sugar beets. M.S. thesis. West Texas A\&M University, Canyon.

7. Finckh, M. R., and Mundt, C. C. 1992. Stripe rust, yield, and plant competition in wheat cultivar mixtures. Phytopathology 82:905913.

8. Finkner, R. E. 1976. Cultivar blends for buffering against curly top and leafspot diseases of sugarbeet. J. Am. Soc. Sugar Beet Technol. 19:74-82.

9. Hariri-Djabbar, Fouchard-Marc, and Prud'homme-Hayat. 2001. Incidence of soil-borne wheat mosaic virus in mixtures of susceptible and resistant wheat cultivars. Eur. J. Plant Pathol. 107:625-631.

10. Harveson, R. M., Hein, G. L., Smith, J. A., Wilson, R. G., and Yonts, C. D. 2002. An integrated approach to cultivar evaluation and selection for increased profitability: a successful case study for the Central High Plains. Plant Dis. 86:192-204.

11. Harveson, R. M., and Rush, C. M. 1994. Evaluation of fumigation and rhizomaniatolerant cultivars for control of a disease complex of sugar beets. Plant Dis. 78:11971202.

12. Harveson, R. M., and Rush, C. M. 1995. Evaluation of cultivar blends and irrigation frequency for control of multiple root rot pathogens of sugar beet. Biol. Cult. Tests Control Plant Dis. 10:19.

13. Harveson, R. M., and Rush, C. M. 1998. Characterization of Fusarium root rot isolates from sugar beet by growth and virulence at different temperatures and irrigation regimes. Plant Dis. 82:1039-1042.

14. Harveson, R. M., and Rush, C. M., and Wheeler, T. A. 1996. The spread of beet necrotic yellow vein virus from point source inoculations as influenced by irrigation and tillage. Phytopathology 86:1242-1247.

15. Hecker, R. J., and Ruppel, E. G. 1975. Inheritance of resistance to rhizoctonia root rot in sugarbeet. Crop. Sci. 15:487-490.

16. Hecker, R. J., and Ruppel, E. G. 1977. Rhizoctonia resistance in sugarbeet: breeding and related research. J. Am. Soc. Sugar Beet Technol. 19:246-256.

17. Mahmood, T., Marshall, D., and McDaniel, M. E. 1991. Effect of winter wheat cultivar mixtures on leaf rust severity and grain yield. Phytopathology 81:470-474.

18. Martin, F. N., and Whitney, E. D. 1990. Inbed fumigation for control of rhizomania of sugar beet. Plant Dis. 74:31-35.

19. Mundt, C. C., Brophy, L. S., and Schmitt, M. S. 1995. Choosing crop cultivars and cultivar mixtures under low versus high disease pressure: a case study with wheat. Crop Prot. 14:509-514.

20. Mundt, C. C., Brophy, L. S., and Schmitt, M. S. 1995. Disease severity and yield of pureline wheat cultivars and mixtures in the presence of eyespot, yellow rust, and their combination. Plant Pathol. 44:173-182.

21. Piccinni, G., and Rush, C. M. 2000. Determination of optimum irrigation regime and water use efficiency of sugar beet grown in pathogen-infested soil. Plant Dis. 84:10671072.

22. Rush, C. M. 1990. Seedling and root rot diseases of sugar beet in Texas. Tex. Agric. Exp. Stn. AREC-CTR 90-4.

23. Rush, C. M., and Harveson, R. M. 1995. Reduction of sugar beet root diseases by cultivar selection and irrigation management. J Sugar Beet Res. 32:157

24. Rush, C. M., and Heidel, G. B. 1995. Furovirus diseases of sugar beets in the United States. Plant Dis. 79:868-875.

25. Rush, C. M., Piccinni, G., and Harveson, R. M. 1997. Agronomic measures. Pages 243 282 in: Environmentally safe approaches to crop disease control. N. A. Rechcigl and J. E. Rechcigl, eds. CRC-Lewis Publishers, Boca Raton, FL

26. Schneider, C. L., Ruppel, E. G., Hecker, R. J., and Hogaboam, G. J. 1982. Effect of soil deposition in crowns on development of Rhizoctonia root rot in sugar beet. Plant Dis. 66:408-410.

27. Schneider, C. L., and Whitney, E. D. 1986 Black root. Page 17 in: Compendium of Beet Diseases and Insects. E. D. Whitney and J. E. Duffus, eds. American Phytopathological Society, St. Paul, MN.

28. Schneider, C. L., and Whitney, E. D. 1986. Rhizoctonia root and crown rot. Page 21 in Compendium of Beet Diseases and Insects. E. D. Whitney and J. E Duffus, eds. American Phytopathological Society, St. Paul, MN.

29. Taylor, H. M., Van Foren, C. E., Godfrey, C. L., and Coover, J. R. Soils of the southwestern Great Plains field station. Tex. Agric. Exp. Stn. MP-669.

30. Trutman, P., Paul, K. B., and Cishabayo, D. 1992. Seed treatments increase yield of farmer varietal field bean mixtures in the central African highlands through multiple disease and beanfly control. Crop Prot. 11:458464.

31. Tuitert, G. 1993. Horizontal spread of beet necrotic yellow vein virus in soil. Neth. J. Plant Pathol. 99: 85-96.

32. Unger, P. W., and Pringle, F. B. 1981. Pullman soils: Distribution, importance, variability, and management. Tex. Agric. Exp. Stn. B1372 .

33. Wolfe, M. S. 1985. The current status and prospects of multiline cultivars and variety mixtures for disease resistance. Ann. Rev Phytopathol. 23: 251-273. 